\title{
Risk assessment of coronavirus disease lockdown on psychosocial support delivery: Eswatini caregivers' perspective
}

\author{
Happyson Bimha', Patronella Bimha², Sibusiso Makhanya ${ }^{3}$
}

${ }^{1}$ Department of Business Administration University of Eswatini, Kwaluseni Campus, Eswatini, ${ }^{2}$ Psychosocial Support Mentor, Institute of Distance Education, University of Eswatini, Kwaluseni Campus, Eswatini, ${ }^{3}$ Child Development and Psychosocial Support Entrepreneur, Eswatini, Kwaluseni Campus, Eswatini

\section{Abstract}

Purpose of the Research: The purpose of the research was to assess the risks of delivering psychosocial support to orphaned and vulnerable children and the impact of COVID-19 lockdown on same. Methodology: Caregivers who are pivotal in managing national care points in Eswatini were targeted in the assessment. A questionnaire was developed based on the identified four risks (material, manpower, machine and technology, and methods risks). Respondents were required to indicate on a five-point Likert scale, probability of the risks happening (very low $=1$ point to very high $=5$ points), the impact risks could cause (very low $=1$ point to very high $=5$ points), and impact of COVID-19 on psychosocial support using a scale of insignificant $=1$ point to critical $=5$ points. Data were collected through WhatsApp and e-mail from 109 (a 72.67\% response rate) caregivers between August and December 2020. Data were statistically analyzed based on means and standard deviations. Findings: Results showed that all the four assessed risks had high chances of happening, could have a high impact on psychosocial support delivery, COVID-19 exacerbated the situation, and authorities imposed restrictive measures which included the closure of national care points. Implications: Major implications for the study are that identifying critical risks could help in prioritizing the risks when planning and allocating resources, lack of strategies to mitigate psychosocial support risks, and their impact threatened the viability of national care points and ultimately vulnerable children. The researchers view the closing of national care points like closing vulnerable children out of food and care, which worsened their predicament. The research recommends accurate assessment of psychosocial support risks and evidence-informed decisions which take into account the special circumstances of disadvantaged children. Originality: The researchers do not have knowledge of any previous studies that studied risks associated with COVID-19 lockdown effects on psychosocial support delivery.

Keywords: Caregivers, coronavirus disease, neighborhood care points, psychosocial support, risk assessment. JEL Classification: M1, M16, H75

\section{INTRODUCTION}

In Eswatini rural communities, the neighborhood care points (NCPs) are the vehicles for delivering psychosocial support to socially disadvantaged children, most of whom are orphaned and vulnerable children (OVC) who lost parents to the scourge of HIV/AIDS (UNICEF, 2008; World Bank,2020). In Eswatini, communal support and caring

*Corresponding author:

Happyson Bimha, Department of Business Administration University of Eswatini, Kwaluseni Campus, Eswatini. E-mail: hbimha@uniswa.sz

Received: March 16, 2021; Accepted: April 18, 2021

DOI: $10.18843 / \mathrm{ijcms} / \mathrm{v} 12 \mathrm{i} 2 / 04$ 
of OVC and other disadvantaged children is a brainchild of rural community mothers. Otherwise, according to the Swazi tradition, the extended family system was expected to take care of family members (children) who needed support after the loss of their parents. The extended family tradition was gradually phasing out and overwhelmed owing to the increase in parental deaths as a result of HIV/AIDS. In 2003, UNICEF decided to partner the community mothers and the partnership consummated the establishment of NCPs and to make OVCs visible. NCPs to provide dayto-day support to the disadvantaged children in Eswatini communities United Nations Programme on HIV/AIDS (UNAIDS 2006). The same author confirms that NCPs are also used as daycare centers for pre-school-age children from socially disadvantaged families who could not afford to enroll their children at privately owned early childhood education centers.

The International Federation of Red Cross and Red Cross Crescent (IFRCRCS, 2001) contends that,

Psychosocial support, guidance, advice and care are traditionally carried out by family or community members. Owing to the breakdown of family and community links traditional support mechanisms are no longer as efficient as they were, where they are, they are likely to breakdown in the aftermath of a disaster or a crisis.

Under Eswatini tradition, NCPs caring for disadvantaged children is the responsibility of the community in which they live (UNAIDS, 2006). However, different stakeholders have different roles to play if the NCPs are to be effective in delivering their mandate of providing psychosocial support services to disadvantaged children. That is why the World Health Organization (WHO) (2020) risk communication, interdisciplinary research, and community engagement to effectively deal with crises such as psychosocial support and recently COVID19. The office of the deputy prime minister houses the National Children's Coordination Unit which is responsible for policy guidance on psychosocial support matters and NERCHA controls Government budget for psychosocial support projects (UNICEF, 2011). Thus, Government provides policy direction, gives grants to allow disadvantaged children enter the formal primary education system, and also provides basic health care services such as immunization, deworming, and child growth monitoring. According to UNICEF (2008), UNICEF provides basic cooking equipment, recreation kits, education, and hygiene materials. World Food Programme (WFP) and other donors provide food which is the biggest need, materials, and other basic necessities, while community members provide provisions such as vegetables and the cleaning of facilities and cooking for the children. Having been trained in the management of NCPs and early childhood support initiatives, the caregivers who work on a voluntary basis manage the NCPs on a daily basis (UNAIDS, 2006). Traditional Governance (local Chiefdoms) has a say in the nomination and appointment of caregivers for psychosocial support projects under their jurisdiction. Participation in these community services is free but NCPs play a boundary-spanning role hence they act as the entry point for organizations which are interested in offering assistance to disadvantaged children in a particular community. The national policy on psychosocial support also notes that a large percentage of Swazi children have found themselves in situations where normal child development processes have been disrupted owing to a myriad of challenges facing the country, including HIV-AIDS and poverty (UNICEF, 2008).

According to International Agencies Standing Committee (IASC, 2007); Inter-agency Network for Education and Emergencies (INEE, 2016) Psychosocial support extends to care and support that is offered by specialized psychological and social services providers to improve the psychosocial well-being of people, building a better sense of self and community, tolerance and acceptance, promoting everyday consistent care and support in the family and community. Psychosocial support must be the concern of all providers, locally, regionally, and nationally.

When health and safety measures such as social distancing, sanitizing, and the wearing of masks were implemented to mitigate the spread of COVID-19, which Sylvia (2020) argued traveled through close contact in droplets expelled from the original host through sneezing, coughing, and just speaking, most NCPs were shut down, and they could not immediately offer psychosocial (PSS) support since the service providers had to adhere to the above measures and other Government induced lockdown rules such as restrictions on traveling from their homes to offer continuous assistance, and inability of children to access face masks as a result of their poverty condition.

Eswatini has a high prevalence of HIV that affects $26 \%$ of its population aged between 15 and 49 years and $45 \%$ of the children are orphaned, while adult life expectancy age is 58.3 years (World Food Programme [WFP], 2018. p. 5). Therefore, most of these disadvantaged/vulnerable children need to get meals from NCPs feeding programs when schools are open. The advent of coronavirus suddenly put the Eswatini vulnerable children in a worse scenario because stringent measures taken by Government 
to suppress the spread of the virus closed the vulnerable children out of feeding points.

To this end, all the highlighted developments could spur several kinds of risks that could contribute to ineffective delivery of psychosocial support initiatives and the failure by NCPs to achieve the national psychosocial support stakeholders' obligations toward OVCs. Based on project management best practices for improving the quality of project delivery in general, some of the risks anticipated under the circumstances to do with PSS delivery include material risks, manpower risks, machine technology risks, and methods risks (Oakland, 2014; Evans and Lindsay, 2017). These risks constitute the research's conceptual framework to be discussed later and also become the basis of the research instrument development.

The researchers envisaged that efforts to contain the spread of the COVID-19 pandemic caused the closure of many institutional projects and the Eswatini NCPs which provide psychosocial support (this is like closing the beneficiaries out of access and availability of food). Further to the blocked access to food, during COVID-19, WHO guidelines that required people to keep social distance, constantly wash hands or sanitize them, and to always wear face masks when going into public places were implemented and these requirements completely grounded down NCP operations. While the NCPs were grounded, the OVCs were at risk without psychosocial support care and locked out of food. Thus, most COVID-19 precautionary measures led to difficulties such as providing the major support of daily meals for the socially disadvantaged children, especially those from grandparent and child-headed households, who usually rely on NCPs meals. Overall, the research tends to support the United Nations' sustainable development goals (SDGs) number 1, 2, and 3, respectively. Goal number one is about ending poverty (social exclusion and vulnerability to natural disasters which undermine economic growth and social cohesion), goal number two is about zero hunger, and it aims to address hunger crisis through sharing of food with those in need and the third goal is about good health and well-being which advocates more funding to health systems, improving sanitation and hygiene. At local level, the research is in line with King Mswati 111's vision 2022 which states that;

The vision's main objective is to improve the standard of living for all our people through access to quality services, wealth creation and employment opportunities. ---We are committed to address issues of poverty and access to quality health, gender equality, social integration and the pursuit of development models which emphasize on environmental protection.
Other potential benefits from the study are: The research is seen as a major contribution to professional stakeholders; hence, research outcomes must shed light on the importance of unity and cooperativeness in PSS project implementation at individual, community, and national levels. Research results have the potential to add new knowledge and information in the psychosocial support field for the benefit of current and future researchers, particularly the benefits of using a multiprofessional approach when researching issues involving multi-sectoral participation. Policymakers and practitioners can also gain knowledge about the sort of decisions they need to make during emergencies such as pandemics.

Government policy clearly states that at NCPs and everywhere you go, the child must be socially and emotionally supported (UNICEF, 2008). In line with this policy, community-driven NCPs were established to make OVCs visible (UNAID, 2006). However, the Government also acknowledges that the scale of orphans and their predicaments are swelling up owing to the collapse of the extended family tradition which made communities custodians of orphans and by extension the OVCs. To support this point, the highest level international coordinating committee in the UN, International Agencies Standing Committee (IASC, 2007), highlights the plight of disadvantaged children by indicating that people affected by crises were being frequently neglected. Despite all this, COVID-19 cornered authorities into making lockdown decisions that seem to be hurting PSS beneficiaries the most instead of supporting them. As a result, the local PSS chapter is in a fix and it urgently requires a rescue package to get it out of this messy. When in such a situation (Hougaard et al., 2020) recommends the presence of a psychosocial safety net, while (Reeves et al., 2020) recommends the use of multidisciplinary approaches which are problem focused. The situation under study does not seem to have both.

The main objective of the research was to assess the risks of delivering psychosocial support to OVC in the Lubombo Region of Eswatini before COVID-19 and during the COVID-19 pandemic. The specific objectives of the study were to identify risks associated with psychosocial support service delivery before and during COVID-19 and assess the extent to which identified risks impacted psychosocial support service delivery before and during COVID-19

\section{LITERATURE REVIEW}

Providing effective psychosocial interventions require collaborative partnerships based on clear roles and 
responsibilities and effective leadership, careful planning, good training and support for personnel at all levels and in all agencies, engaged, informed, and resilient communities, effective communication, and regular monitoring and evaluation (New Zealand Ministry of Health, 2016). Psychosocial support during an emergency, no matter how long it lasts, is about easing the psychological, social, and physical difficulties for individuals, families, and communities (Ibid). Therefore, the primary objectives of psychosocial recovery are to minimize the physical, psychological, and social consequences of an emergency and to enhance the emotional, social, and physical wellbeing of individuals, families, and communities. Psychosocial recovery is not about returning to normality. It is about positively adapting to a changed reality. Therefore, those affected must be educated about the new normal and prepared to survive under the new reality. When dealing with these issues, Ministry of Health (2016) in New Zealand advocates evidence-informed policy and practices and timely delivery of appropriate psychosocial support interventions to support the affected individuals and communities.

Mattingly (2017) notes that many Governments respond to psychosocial support-related disasters by putting in place projects and programs to deal with such developments because natural disasters such as COVID-19 can bring about psychological and social suffering to the affected people. The affected lose the normal support from families and community because everyone will be under stress. According to Mattingly (2017), vulnerability of the affected individuals can be exacerbated by social inequalities, poverty, low education, and area of residence. Thus, the psychosocial support withdrawal is likely to affect the Swazi rural community, whose social conditions are already compromised. This can further be spurred by measures taken by Government and its aid agencies, particularly where material support is withdrawn and community participation in determining solutions is limited or non-existent. This was evidenced by the Government's decision to lock down the country, to close NCPs and other institutions as the main strategy to restrict the spread of COVID-19.

Mahaveer (2020), commending on lockdown in India, observed that most nations across the world implement lockdown measures with stringent restrictions to break the chain of COVID-19 transmissions, but this could lead to further psychosocial difficulties for OVCs whose families have no means to feed and look after them. The author added that economic, social, and cultural disparities make lockdowns a hard measure for poorer sections of society.
As a result, there was a need to build community-based local capacity to handle local issues because different communities have different situations that require different solutions. This idea is supported by the WHO (2020; The World Bank, 2020) which emphasized that the COVID-19 crisis was not going to be controlled without community participation because, ultimately, control must be based on individual behavior. The WHO also backed the continued availability and accessibility of community-based services.

\section{Project Risk Management}

Project risk is a critical component of a project of any nature and magnitude across the spectrum. Therefore, project management scholars and researchers advocate that project risk management must be at the forefront of implementing projects in Government, Private sector, Non-Governmental Organizations, and any other set up which utilizes project management as a tool for achieving organizational goals and objectives (Project Management Institute, 2008; Kaplan and Miles, 2012; Oosthuizen and Venter, 2012; Kloppenborg et al., 2019). Project risk has been defined as anything that may impact the project team's ability to achieve the general project success measures and the specific project stakeholders priorities (Kloppenborg et al., 2019. p. 31) or any unwanted event or situation that can lead to the failure of your project (Majeed, 2018). Project success measures entail meeting project deliverables, meeting customers' expectations, helping the organization achieve its future targets, and meeting project teams expectations (Kloppenborg et al., 2019). The same authors observe that project stakeholders' priorities are project scope, quality of deliverables, implementing project activities on time, and project contribution to the organization and to society. The project risk management plan addresses the process behind risk management (Chandana, 2017). The steps in this process include risk identification, risk analysis, risk response strategies, and risk controlling (Fox and Van Der Waldt, 2007; Project Management Institute, 2008; Meredith et al., 2016). Therefore, risk planning may assist project managers to identify what worked well and what did not go well in the project, implying strategies are required to deal with project risks on a continual basis.

During the risk identification phase, a list of risks that have the potential to affect a project is drawn. The list can further be categorized into internal or preventable risks and external risks. Kaplan and Miles (2012) contend that preventable risks are internal risks emanating from within the project. These risks are preventable in the sense that management has overall authority to manage and control 
these risks. Accordingly, preventable risk can be eliminated and avoided if it is within management's risk tolerance zone. The external risks arise from outside the organization and are beyond management influence and control (Ibid). The likes of natural disasters, pandemics such as COVID-19, macroeconomic, and political shifts fit well in this category. However, the fact that management cannot prevent external risks from occurring does not mean that management cannot do something, they can focus on identifying and mitigating the impact of such risks should they occur (Kaplan and Miles, 2012). The probability that external risks will occur is generally low, making advance planning for the same during the organization's strategy development difficult. According to Majeed (2018), the key to successful project risk management is constantly updating the risk list, while ensuring that project team members are aware of the risks specific to their own tasks. Related to this is an observation by Fox and Van Der Waldt (2007), who note that issues and risks can be raised by anyone involved in the project or its stakeholders throughout its life cycle. In light of this view, caregivers who are at the center of psychosocial support delivery in Eswatini were identified as the respondents and units of analysis in the study.

During the risk analysis phase, risks identified in phase one are qualitatively or quantitatively assessed in terms of the impact each risk will have if it occurs, the likelihood or the probability that the risk will occur, and the strengths of existing controls (Kaplan and Miles, 2012). The level of rigor involved will be determined by the riskiness of the project (Oosthuizen and Venter, 2012). According to Chandana (2017), risk assessment is the determination of qualitative or quantitative value of risk related to a concrete situation and a recognized threat through measuring the probability that the risk will become a reality. The process allows the organization to identify, categories, prioritizes, and mitigates risks ahead of time (Ibid). This process helps you understand project risks better so that decisions on which risks need to be carefully managed are taken from an informed position (Kloppenborg et al., 2019). Enshrined in this risk description is the fact that management is interested in risks that matter. Risk which impacts your project objectives of time, budget, scope, and quality should they happen is the one that matters (Project Management Institute, 2008; Oosthuizen and Venter, 2012; Meredith et al., 2016).

The qualitative risk analysis classifies both the seriousness and probability of risk as high, moderate, and low (Chandana, 2017). These risk classifications can be further broken down into five-point scale such as very low, low, moderate, high, and very high depending on the level of detail required (Oosthuizen and Venter, 2012). In Kloppenborg et al. (2019)'s view, the two questions that the qualitative analysis assesses are how likely is the risk to happen and if the risk happens, how big will the impact be. Therefore, the process groups' risks into major and minor risks, a distinction which makes management avoid the risk of ignoring all risks or treating all of them as major risks (Ibid). Oosthuizen and Venter (2012) argue that when one has identified the risks, it will nether be neither possible nor desirable to put all of them at the same level of attention. Both the risks and their responses ought to be prioritized for effective risk management on the entire project. It is important to reiterate the point that each identified risk requires a specific strategy and program of action so that resources are channeled where they are needed most, risks that pose a high impact to the project and a high chance of occurring.

In general accepted risk response strategies are avoidance or eliminating uncertainty, mitigation or involving others, and acceptance or taking the risk as it comes (Oosthuizen and Venter, 2012). Risk avoidance can entail changing a product design or the development process and deciding not to do a project (Kloppenborg et al., 2019). Same author adds that risk could also be transferred to others, for example, taking insurance policy or hiring consultancy. Mitigating the impact of any risk requires one to develop contingency plans in case a risk occurs (Kaplan and Miles, 2012). Mitigation can also entail using more effective methods. Acceptance means the risk is accepted and no further action will be taken, implying accepting whatever consequences a risk brings about (Meredith, 2016; Kloppenborg et al., 2019). This is common with minor risks which will not have a high impact when they occur and high impact risks which cannot be identified and planned in advance such as the COVID-19 pandemic. Carr et al. (1993) added that studying a risk further to acquire more information is another important strategy for decision-makers. According to Oosthuizen and Venter (2012. p. 241), risk response can also be divided into reactive risk response strategies and proactive risk response strategies. Like in the COVID19 pandemic, reactive strategies limit the consequences emanating from events that have occurred, while proactive risk response strategies involve actions done in anticipation of risk occurring in future.

Risk controlling involves a risk management plan as the main input that identifies the risks, the tools that are used in managing or controlling the risks, and outputs which are part of the risk response effects and checklists based on corrective actions implemented for the project (Fox and Van Der Waldt, 2007). Risk consequences may include lower revenues, falling stock prices, bad public image of the company, and bankruptcy (Bech, 2018). The benefits 
of embarking on a risk management plan were summarized by Majeed (2018) as it helps you avoid any big disaster, emphasizes your revenues by saving your expenses, provides you mental satisfaction, ensures successful completion of project, gives you competitive edge over others, increases the sense of responsibility and accountability and helps you explore new opportunities.

Project success, even during risk situations, is associated with certain success factors. Success factors may include agreement among project team and stakeholders on the goals and objectives of the project, support from top management who supply required resources, and remove organizational obstacles and effective communication which is appropriately delivered and ongoing (Fox and Van Der Waldt, 2007).

The conceptual framework for the study is summarized by the Ishikawa (fishbone) diagram in Figure 1.

The effectiveness of a work center, for example, and NCP, or a project can be analyzed based on the elements that spur its capacity to achieve its objectives. These elements can prevent the project from achieving its objective, rendering it ineffective. In project management and related professions such as operations management and supply chain management, the continued effectiveness of a system can be explained using the fishbone or Ishikawa diagram [Figure 1]. The diagram symbolizes a skeleton of a fish. In the model, the fish head represents the project's main problem-psychosocial support objectives which have not been met, implying lack of effectiveness. Identification of the actual reasons for ineffectiveness can be achieved by carrying out a thorough analysis of key elements of delivering a psychosocial support program in an effective manner. These elements include man (manpower), machine (technology), methods (strategies), measurements (assessment of work done), and material and mother nature (in the study this will be COVID-19).

Manpower-In an organization staff is considered to be key assets which project managers must give the requisite treatment. When it comes to a decision making, it has been argued that companies will get nowhere if all the thinking is left to management (Atkinson, 2014). There must be devolution of decision-making powers that will allow participation by those involved in implementing company strategies (Thuis and Stuive, 2012; Schermerhorn and Bachrach, 2015). This kind of participation and involvement motivates staff and encourages them to work harder.

Machines denote to the use of appropriate technology and equipment as an effort to achieve project objectives as effectively and efficiently as practicable. Use of technology and the right tools delineates the need of more employees using manual labor (Evans and Lindsay, 2017). Use of appropriate equipment and technology ensures employees are safe and protected. Since the advent of COVID-19, there has been a sudden increase in demand for personal protective equipment (PPE) for workers, especially those who deal with the public. Insufficient supply of PPE has been a major concern in all countries but less developed countries such as Eswatini were affected more seriously owing to limited budgets and limited manufacturing capacity, as explained in the next paragraph.

Methods or strategies are part of an organization's processes which are employed in carrying out tasks allocated to individual employees or groups of employees. There have been several reports about procurement corruption in the acquisition of COVID-19 supplies. In South Africa, Mhlanga (2020) of Corruption Watch wrote that over 600 companies that were awarded COVID-19 supplies tenders for masks, sanitizers, and surgical gloves were being investigated for over R5 billion procurement frauds. Such corrupt practices usually prevail where there is discord, lack of coordination and communication, poor planning and monitoring, and insufficient control mechanisms. On July 7, 2020, Mutsaka, 2020 of AP news reported that Zimbabwe's health Minister was fired over a COVID-19 graft scandal in the award of a \$28 million dollar tender to a briefcase businessman who overcharged the Government for the supplies. In Eswatini, Hlatshwayo, (2020) of the Times of Swaziland wrote on August 2 that COVID-19 tests were not being done because lab technicians were striking for PPE. The situation was reported to be the same with other health personnel, as confirmed by the president of the Swaziland Democratic Nurses Union (SWADNU). At NCPs, caregivers closed shop and went home, preventing OVCs to access PSS services. Employees require protection, education, and training to become more effective and more productive based on their ability to understand these strategies (Oakland, 2014). Training and awareness will help the workers to be more innovative and think out of the box.

Measurement of performance against set objectives is a critical controlling and compliance technique which enables workers to get feedback on whether they are on track, behind schedule, or ahead of schedule. Assessment results are good for reviewing strategies, budgets, and rescheduling tasks (Oakland, 2014). Thus, use of risk assessment tools such as the selected fishbone diagram can assist in quickly identifying what is wrong and help both management and workers put heads together in developing feasible solutions. 
Material constitutes inputs for the project and refers to resources that staff requires as inputs to their processes, resources used to convert inputs into outputs, and resources used for handling, packaging, loading, and serving clients. The availability, amount, and quality of materials can be used to give emotional support to the affected (Dhital et al., 2019; Collins, 2020). Poor and inadequate material may cause delays leading to dissatisfaction among clients (Evans and Lindsay, 2017).

Mother nature refers to natural events which are God-given or directives made by government. For example, COVID-19 is a God-given event which forced Governments to unilaterally lockdown their countries, forcing company closures, travel restrictions, and social distancing requirements. In business, other environmental factors such as social, legal, economic, political, and technological factors create risks for projects and companies. To effectively manage externally driven risks such as pandemics, individual organizations, or Ministries cannot go it alone, they need to cooperate with other stakeholders (Thuis and Stuive, 2012; Schermerhorn and Bachrach, 2015).

In the fishbone model, arrows leading to the main elements are the fish's hooked bones. These bones are sub-divided into smaller hooks and bones which represent smaller components that make up the bigger bones. The subdivision goes on till the bones cannot be split further. In problem or risk analysis, this means elements that lead to the main problem must be broken down till you cannot collect further reasons why there is a problem under each element. The smaller bones and their subsequent attributes are the items that the researchers used to develop the instrument used in the study. In the same analysis, one can ask "why" something is a problem five times to exhaust the analysis. The five why the technique was founded by Sakichi Toyoda, founder of Toyota Industries, back in the 1930s, as a tool that would assist decision-makers to get to the root causes of problems before they make decisions. The researchers felt interrogating the ineffectiveness of psychosocial support in this fashion would lead to a more detailed and informative analysis that is valuable in turning around the psychosocial support services sector's problems.

\section{MATERIALS}

Risks in psychosocial support services delivery require to be assessed in detail; hence, the reference to the fishbone diagram model above which assisted in the prior identification of PSS risks that caregivers could be facing. Time and resources would not permit the researchers to assess all the elements of the fishbone diagram but focused on material risk, machine and technology risk, methods risk, and manpower risk. Based on the information given in the study's background and the reviewed literature, the researchers felt that these four risks were more relevant and will be adequate to address risks facing PSS program management in Eswatini. The four risks forming the research were broken down into five-point Likert scale items that addressed more specific issues as reflected in the research instrument and these are the questions which the psychosocial support caregivers answered.

The premise of this study was to undertake an assessment of the situation of risk management in the provision of psychosocial support services in Eswatini, particularly during the COVID-19 pandemic. Fox and Van Der Waldt (2007) note that issues and risks can be raised by anyone involved in the project or its stakeholders throughout its life cycle. In the Eswatini PSS, program caregivers are at the center of PSS delivery because they manage the NCPs which are the main vehicle for delivering PSS services in the country.

Risk assessment was conducted among psychosocial support caregivers in NCPs in the Lubombo Region of Eswatini between August and December 2020. The Lubombo Region was selected based on the severity of psychosocial support problems in the Region. According to UNAID (2006), the Lubombo community struggles to feed itself and as a result $99 \%$ of the food distributed to vulnerable and disadvantaged children through NCPs comes from donors.

To adequately cater for the complex nature of caring for vulnerable and disadvantaged children, the multidisciplinary research arrangement was preferred. The research team was made up of educational psychology and health sciences specialist, business and project management specialist, and a psychosocial support and child development specialist. A quantitative research questionnaire was developed based on the four domains or themes from the fishbone diagram. Items were developed and placed under each of the four themes. All the questions required the 150 purposively selected caregivers from Lubombo NCPs to indicate on a five-point Likert scale if they perceived the selected risks as having very low (1 point) to very high (5 points) probability of happening or having the capacity to cause very low ( 1 point) to very high ( 5 points $)$ impact to the psychosocial support program if they occurred. The third dimension asked respondents about the impact of COVID19 on psychosocial support services using a scale of insignificant (1 point) to critical (5 points). The idea was to 
identify critical risks so that they could be prioritized when planning and allocating resources.

Although the research tends to be overly quantitative in nature based on the quantitative and statistical analysis, the researchers employed a qualitative risk assessment technique that was used to draw up the list of critical risk factors and proposed how they could be managed. Multiple methods were employed to distribute the research questionnaire. Employing snowballing and using local area networks, the researchers obtained cell numbers of the caregivers. The research questionnaires were sent through e-mail and WhatsApp. Responses were received, physically, through WhatsApp, and e-mail. The researchers also had to phone some of the participants who opted to provide feedback through voice calls and the researchers had to complete the questionnaires in this later mode. A total of 109 analyzable forms were received in the study. This represents a $72.67 \%$ response rate which the researchers considered good under the COVID-19 travel and interactions restrictions. Please note that all the abbreviations used in the questionnaire were clearly defined and explained in the instrument.

\section{RESULTS}

Data for the survey were processed using the IBM SPSS Version 20 and quantitatively analyzed in terms of frequencies and percentages, means, and standard deviations. However, the researchers felt that presenting the results based on means and standard deviations alone is adequate for the purpose of explaining the objectives of the study which were to identify risks associated with psychosocial support service delivery before and during COVID-19 and to assess the extent to which identified risks impacted psychosocial support service delivery before and during COVID-19.

Section A of the instrument surveyed the probability of different identified psychosocial support risks occurring. Overall, the results were processed under the following ranges of the mean:

Means below 1.45 are interpreted as very low, means between 1.45 and 2.44 are interpreted as low, means between 2.45 and 3.44 are interpreted as moderate, means between 3.45 and 4.44 are interpreted as high, and means above 4.44 are interpreted as very high.

Regardless of which of the four subsections a risk belonged to, responses were listed from the item with the highest mean to the lowest. Therefore, caregivers considered poor funding of PSS (5.0000), poor supply of food for OVC (4.9908), lack of PPE for caregivers (4.9908), lack of Information and Communication Technology (ICT) (4.8807), and lack of modern cooking equipment (4.4495) as very high risks facing psychosocial support services in Eswatini. Otherwise, all the risks were assessed as high (3.6697) to very high (5.0000) risks. (Table 1)

Domain means are a result of collapsing the individual items into subsections. All the four subsection-level risks were assessed and viewed as high to very high risks. The highest risk is material risk (4.9939), followed by machine and technology risk (4.7584), methods risk is on third position (4.3889), and last is manpower risk (4.1529).

Section B of the instrument surveyed the impact of the different identified psychosocial support risks if and when they occur. Overall, the results were processed under the following ranges of the mean:

Means below 1.45 are interpreted as insignificant impact, means between 1.45 and 2.44 are interpreted as low impact, means between 2.45 and 3.44 are interpreted as moderate, means between 3.45 and 4.44 are interpreted as high impact, and means above 4.44 are interpreted as very critical. (Table 2)

Regardless of which of the four subsections a risk belonged to, responses were listed from item with the highest impact to the one with insignificant impact. Therefore, caregivers considered a poor supply of food for OVCs (5.0000), lack of PPE for caregivers (5.0000), poor funding of PSS programs (4.9817), lack of ICT (4.9266), lack of modern cooking equipment (4.678), and lack of transport (4.6697) as having a critical impact to the delivery of psychosocial support services in Eswatini. Otherwise, all the other risks have high impact ranging from 3.9908 to 4.4074 . (Table 3 )

Table 4 shows that this subsection's means for risk impact on PSS services all reflect a high impact of 4.1529 to critical impact of 4.9939. Material risk and machine and technology risks have a critical impact, while methods and manpower risks have high impact.

Section C of the instrument surveyed the impact of COVID-19 on psychosocial support services. Overall, the results were processed under the following ranges of the mean:

Means below 1.45 are interpreted as insignificant, means between 1.45 and 2.44 are interpreted as low, means 
between 2.45 and 3.44 are interpreted as moderate, means between 3.45 and 4.44 are interpreted as high, and means above 4.44 are interpreted as critical.

\section{Table 1: Item means for the probability that the} identified risks will occur

\begin{tabular}{|c|c|c|c|}
\hline \multirow{2}{*}{$\begin{array}{l}\text { Description of } \\
\text { psychosocial } \\
\text { support risk }\end{array}$} & $\begin{array}{l}\text { Respondents } \\
\text { (N) }\end{array}$ & \multirow[t]{2}{*}{ Mean } & \multirow[t]{2}{*}{$\begin{array}{l}\text { Standard } \\
\text { deviation }\end{array}$} \\
\hline & Caregivers & & \\
\hline $\begin{array}{l}\text { Poor funding of } \\
\text { PSS programs }\end{array}$ & 109 & 5.0000 & 0.0000 \\
\hline $\begin{array}{l}\text { Poor supply of food } \\
\text { for orphaned and } \\
\text { vulnerable children }\end{array}$ & 109 & 4.9908 & 0.0978 \\
\hline $\begin{array}{l}\text { Lack of PPE for } \\
\text { caregivers }\end{array}$ & 109 & 4.9908 & 0.0978 \\
\hline $\begin{array}{l}\text { Lack of } \\
\text { Information and } \\
\text { Communication } \\
\text { Technology }\end{array}$ & 109 & 4.8807 & 0.32560 \\
\hline $\begin{array}{l}\text { Lack of modern } \\
\text { cooking equipment }\end{array}$ & 109 & 4.4495 & 0.53552 \\
\hline Lack of transport & 109 & 4.3945 & 0.57764 \\
\hline $\begin{array}{l}\text { Ineffective PSS } \\
\text { strategies }\end{array}$ & 108 & 4.3148 & 0.52326 \\
\hline $\begin{array}{l}\text { Weak PPS delivery } \\
\text { processes }\end{array}$ & 109 & 4.2966 & 0.33234 \\
\hline $\begin{array}{l}\text { Poor coordination } \\
\text { of NCP activities }\end{array}$ & 109 & 4.2661 & 0.53821 \\
\hline $\begin{array}{l}\text { Poor cooperation } \\
\text { from community } \\
\text { members }\end{array}$ & 109 & 3.8990 & 0.77068 \\
\hline Inadequate staff & 109 & 3.8165 & 0.78369 \\
\hline $\begin{array}{l}\text { Ineffective } \\
\text { leadership }\end{array}$ & 109 & 3.6697 & 0.68116 \\
\hline
\end{tabular}

Source: Research data 2021. NCP: Neighborhood care points, PPE: Personal protective equipment

Table 2: Domain means for the items in Table 1: Probability of identified risk items happening

\begin{tabular}{lccc}
$\begin{array}{l}\text { Description } \\
\text { of domain } \\
\text { psychosocial } \\
\text { support risk }\end{array}$ & $\begin{array}{c}\text { Respondents } \\
(\mathbf{N}) \\
\text { Caregivers }\end{array}$ & Mean & $\begin{array}{l}\text { Standard } \\
\text { deviation }\end{array}$ \\
\hline Material risk & 109 & 4.9939 & 0.06386 \\
$\begin{array}{l}\text { Machine and } \\
\text { technology risk }\end{array}$ & 109 & 4.7584 & 0.34508 \\
Methods risk & 109 & 4.3889 & 0.46586 \\
Manpower risk & 108 & 4.1529 & 0.63267 \\
\hline
\end{tabular}

Source: Research data 2021
Regardless of which of the four subsections a risk belonged to responses were listed from item that was mostly affected by COVID-19 to the least affected items. Therefore, caregivers considered poor supply of food for OVCs (5.0000), lack of PPE for caregivers (5.0000), funding of PSS programs

Table 3: Item mean results showing the impact that the identified psychosocial support risks will have if and when they happen

Description of Respondents Mean Standard psychosocial (N) deviation support risk Caregivers

\begin{tabular}{|c|c|c|c|}
\hline $\begin{array}{l}\text { Poor supply of food } \\
\text { for orphaned and } \\
\text { vulnerable children }\end{array}$ & 109 & 5.0000 & 0.0000 \\
\hline $\begin{array}{l}\text { Lack of PPE for } \\
\text { caregivers }\end{array}$ & 109 & 5.0000 & 0.0000 \\
\hline $\begin{array}{l}\text { Poor funding of } \\
\text { PSS programs }\end{array}$ & 109 & 4.9817 & 0.19157 \\
\hline Lack of ICT & 109 & 4.9266 & 0.26199 \\
\hline $\begin{array}{l}\text { Lack of modern } \\
\text { cooking equipment }\end{array}$ & 109 & 4.6789 & 0.46906 \\
\hline Lack of transport & 109 & 4.6697 & 0.51058 \\
\hline $\begin{array}{l}\text { Weak PPS delivery } \\
\text { processes }\end{array}$ & 108 & 4.4074 & 0.49344 \\
\hline $\begin{array}{l}\text { Ineffective PSS } \\
\text { strategies }\end{array}$ & 108 & 4.3796 & 0.48766 \\
\hline $\begin{array}{l}\text { Poor coordination } \\
\text { of NCP activities }\end{array}$ & 109 & 4.3853 & 0.48892 \\
\hline $\begin{array}{l}\text { Poor cooperation } \\
\text { from community } \\
\text { members }\end{array}$ & 109 & 4.2569 & 0.73791 \\
\hline Inadequate staff & 109 & 4.2110 & 0.68441 \\
\hline $\begin{array}{l}\text { Ineffective } \\
\text { leadership }\end{array}$ & 109 & 3.9908 & 0.72642 \\
\hline
\end{tabular}

Source: Research data 2021. NCP: Neighborhood care points, PPE: Personal protective equipment

\section{Table 4: Domain means for the items in Table 3:} Impact of identified risk if they happen

Description of Respondents (N) Mean Standard psychosocial Caregivers deviation support risk

\begin{tabular}{lccc} 
Material risk & 109 & 4.9939 & 0.06386 \\
$\begin{array}{l}\text { Machine and } \\
\text { technology risk }\end{array}$ & 109 & 4.7584 & 0.34508 \\
Methods risk & 108 & 4.3899 & 0.46586 \\
Manpower risk & 109 & 4.1529 & 0.63267 \\
\hline
\end{tabular}

Source: Research data 2021 
Table 5: Item mean results showing the impact of COVID-19 on psychosocial support services

\begin{tabular}{lcc}
$\begin{array}{l}\text { Description of } \\
\text { psychosocial } \\
\text { support risk }\end{array}$ & Respondents (N) Mean & $\begin{array}{l}\text { Standard } \\
\text { deviatio }\end{array}$ \\
\hline
\end{tabular}

\begin{tabular}{|c|c|c|c|}
\hline $\begin{array}{l}\text { Poor supply } \\
\text { of food for } \\
\text { orphaned and } \\
\text { vulnerable } \\
\text { children }\end{array}$ & 108 & 5.0000 & 0.0000 \\
\hline $\begin{array}{l}\text { Poor supply } \\
\text { of PPE for } \\
\text { caregivers }\end{array}$ & 108 & 5.0000 & 0.0000 \\
\hline $\begin{array}{l}\text { Poor funding of } \\
\text { PSS programs }\end{array}$ & 108 & 4.9815 & 0.13555 \\
\hline Lack of ICT & 108 & 4.7130 & 0.4449 \\
\hline $\begin{array}{l}\text { Lack of } \\
\text { modern } \\
\text { cooking } \\
\text { equipment }\end{array}$ & 108 & 4.4815 & 0.59119 \\
\hline $\begin{array}{l}\text { Lack of } \\
\text { transport }\end{array}$ & 108 & 4.4855 & 0.59119 \\
\hline $\begin{array}{l}\text { Poor } \\
\text { cooperation } \\
\text { from } \\
\text { community }\end{array}$ & 108 & 4.2593 & 0.44027 \\
\hline $\begin{array}{l}\text { Poor } \\
\text { coordination of } \\
\text { NCP activities }\end{array}$ & 108 & 4.2155 & 0.50195 \\
\hline $\begin{array}{l}\text { Inadequate } \\
\text { staff }\end{array}$ & 108 & 4.2222 & 0.41788 \\
\hline $\begin{array}{l}\text { Ineffective } \\
\text { PSS strategies }\end{array}$ & 108 & 4.2222 & 0.41788 \\
\hline $\begin{array}{l}\text { Weak PPS } \\
\text { delivery } \\
\text { processes }\end{array}$ & 108 & 4.1852 & 0.39026 \\
\hline $\begin{array}{l}\text { Ineffective } \\
\text { leadership }\end{array}$ & 108 & 4.1389 & 0.39762 \\
\hline
\end{tabular}

Source: Research data 2021. NCP: Neighborhood care points, PPE: Personal protective equipment

(4.9815), provision of ICT (4.7130), lack of modern cooking equipment (4.4815), and lack of transport (4.4815) as areas critically impacted by COVID-19. COVID-19 also had a high impact on the rest of the items ranging from 3.9908 to 4.4074, having critical impact to the delivery of psychosocial support services in Eswatini. Otherwise, COVID 19 had a high impact ranging from 3.9908 to 4.4074 on all the other items. (Table 5)

\begin{tabular}{|c|c|c|c|c|}
\hline S. No & $\begin{array}{l}\text { Risk } \\
\text { description } \\
\text { deviation }\end{array}$ & $\begin{array}{c}\text { Respondents } \\
\text { (N) } \\
\text { Caregivers }\end{array}$ & Mean & Standard \\
\hline 1. & $\begin{array}{l}\text { Material } \\
\text { risk impact }\end{array}$ & 108 & 4.9938 & 0.04115 \\
\hline 2. & $\begin{array}{l}\text { Machine } \\
\text { and } \\
\text { Technology } \\
\text { risk impact }\end{array}$ & 108 & 4.5586 & 0.42952 \\
\hline 3. & $\begin{array}{l}\text { Manpower } \\
\text { risk impact }\end{array}$ & 108 & 4.2688 & 0.36944 \\
\hline 4. & $\begin{array}{l}\text { Methods } \\
\text { risk impact }\end{array}$ & 108 & 4.2130 & 0.39587 \\
\hline
\end{tabular}

In Table 6, Domain means results show that COVID 19 had a critical impact on materials (4.9938) and machine and technology risk (4.5586) and it had a high impact on manpower (4.2688) and methods (4.2130).

\section{Demographic Data}

Demographic data were analyzed based on frequencies and percentages.

Table 7 shows that the majority of the caregivers are 25-60 years old (93.8\%), 2 people are below 25 years old and are above 60 years.

Table 8 shows that NCPS in the Lubombo Region were staffed with experienced caregivers. Only $10.5 \%$ had $<5$ years' experience, $76.2 \% 5-15$ years, and the balance of $13.3 \%$ have more than 15 years' experience.

Other demographic data revealed that all the respondents were female, $21 \%$ received psychosocial support training while $79 \%$ did not receive any training. All the participants did not get any compensation for their services and even after COVID $19,72.4 \%$ of the participants said they were willing to continue, while $27.6 \%$ were no longer willing to continue. Reasons for continuing or not continuing are summarized below.

Ninety-two (92\%) of the total respondents (105) said they will continue looking after OVCs and they were doing this out of passion, they wanted to help children in their community. However, $20 \%$ of them needed to be 
compensated for their services. Only 1 participant said she wanted to utilize her psychosocial support certificate.

Participants who said they will not continue after COVID-19 sighted different reasons such as they were tired of working without compensation (15), they are relocating to another community (1), going to advance their education (2), got new job elsewhere (2), age and ill-health (7), demotivated by not being recognized in the system (1), and family reasons (7). Examples of family reasons given were that partners lost their jobs or business under COVID-19; hence, family resources were affected. However, some family members suspected that the volunteer workers we being paid but did not want to contribute to family expense hence their relations were being affected.

\section{DISCUSSION OF STUDY FINDINGS}

The discussion section of the research is based on the research objectives. The first research objective was to identify risks associated with psychosocial support service delivery before and during COVID-19. The objective was achieved in section A of the instrument which identified the different PSS risks and the probability that they can occur. Four domain risks were identified and each of them was further broken down into three specific risks, as shown in Table 9.

\begin{tabular}{lcc}
\multicolumn{3}{c}{ Table 7: Age of participants $(\boldsymbol{n = 1 0 5})$} \\
Age range (year) & Frequency & Percent \\
\hline Below 25 & 2 & 1.9 \\
$25-30$ & 14 & 13.3 \\
$31-40$ & 39 & 37.7 \\
$41-50$ & 27 & 25.7 \\
$51-60$ & 18 & 17.1 \\
Above 60 & 5 & 4.8 \\
Total & 105 & 100 \\
\hline
\end{tabular}

Source: Research data 2021

Table 8: How long participants have worked in NCPs $(n=105)$

\begin{tabular}{lcc} 
Age range (year) & Frequency & Percent \\
\hline Below 5 & 11 & 10.5 \\
5-below 10 & 33 & 31.4 \\
10-below 15 & 47 & 44.8 \\
Above 15 & 14 & 13.3 \\
Total & 105 & 100 \\
\hline Source: Research data 2021. NCPs: Neighborhood care points
\end{tabular}

Projects are change management initiatives introduced by management in an organization. Therefore, some proponents of project management posit that in any change program and by extension in any project one cannot avoid the risk element (Chandana, 2017; Bech, 2018). Since change and risk are close buddies, the moment one introduces a project, there is a need to have a clear picture of the risks that are associated with the project, knowing what the risks are, the nature of the risks, and how they will impact the project and lastly how they should be managed (Kaplan and Miles, 2012). So, in any project, at any point in time, one needs to identify project risks and mitigate their impact to the project.

The study's second objective was to assess the extent to which identified risks impacted psychosocial support service delivery before and during COVID-19. Section $\mathrm{B}$ of the questionnaire assessed the impact of the risks on PSS services in general and section $\mathrm{C}$ of the questionnaire assessed the impact of COVID-19 on PSS services. Mattingly (2017) observed that natural disasters (the researchers feel COVD-19 qualifies to be one) can bring about psychological and social suffering for the affected people who lose normal support from families and communities. The same author emphasizes that the problem of the affected will be spurred by decisions taken by Government and its agencies in the name of protecting or helping them. For example, health risks paused by COVID19 forced the Government to make lockdown decisions to mitigate the spread of COVID-19. However, this led to the closure of NCPs which meant closing the OVCs out of food. Results linked to section A of the questionnaire show that part of the PSS risk factors with a high probability of happening such as poor funding of PSS programs, lack of ICT, lack of modern cooking equipment, and transport could be external factors. In management, managers are

\begin{tabular}{|c|c|}
\hline $\begin{array}{l}\text { Domain risk } \\
\text { description }\end{array}$ & Specific risk items \\
\hline Material risk & $\begin{array}{l}\text { Food for the orphaned and vulnerable } \\
\text { children, PPE for caregivers, and } \\
\text { funding for PSS services }\end{array}$ \\
\hline $\begin{array}{l}\text { Machine and } \\
\text { technology risk }\end{array}$ & $\begin{array}{l}\text { ICT, Modern cooking equipment, and } \\
\text { transport }\end{array}$ \\
\hline Methods risk & $\begin{array}{l}\text { Coordination of NCP activities, PSS } \\
\text { strategies, and PSS delivery processes }\end{array}$ \\
\hline Manpower risk & $\begin{array}{l}\text { Leadership, staff, and cooperation from } \\
\text { community members }\end{array}$ \\
\hline
\end{tabular}

Source: Research data 2021. NCP: Neighborhood care points, PPE: Personal protective equipment 
usually not blamed for problems associated with external factors because it does not have control over such issues. However, project management specialists Kaplan and Miles (2012) argue that the fact that management cannot prevent external risks from occurring does not mean that management cannot do something, they can focus on identifying those risks and mitigating the impact they will have on a project if they occur. To exacerbate the Kaplan and Miles (2012) argument, the study revealed that even the internal risks which management are assumed to have control on are considered as high-risk items, none of them is in the category low to moderate, they are all lumped in high to very high-risk categories. Issues to do with ineffective leadership, inadequate staff, poor cooperation, and poor coordination, and ineffective strategies are internal issues that management must deal with. In this regard, the New Zealand Ministry of Health (2016) advocates teamwork that entails collaborative partnerships, effective leadership, good training and support of personnel, resilient, and healthy relations with communities.

In section $\mathrm{B}$ of the questionnaire, the interest was on identifying risks with the highest impact if they happen. Kloppenborg et al. (2019) note that management is interested in risks that matter, those risks with threaten the attainment of project objectives when they occur. Research results show the poor supply of food for OVCs, lack of PPE for caregivers, and poor funding as the top three risks with the largest impact, but the rest of the items have high impact when they occur as well. Procurement malpractices discussed in the literature section can be associated with the top three risks and all the others too. For example, use of appropriate equipment and technology ensures employees are safe and protected (Atkinson, 2014). In the study, literature reveals that employees have to strike for their safety and protection. It is especially worrisome when caregivers reveal that they are under threat from their own leadership, the strategies they design and the processes through which the strategies must be operationalized. It is unfortunate that the caregivers were not asked to explain the risks they are complaining about. The New Zealand Ministry of Health (2016) emphasized that those risks cannot be wished away, people particularly Government need to find appropriate solutions.

Section $\mathrm{C}$ of the questionnaire strictly focused on the impact of COVID-19 on PSS services. Although this may not be measured strictly by quantitative metrics, the ensuing results give us an idea of what COVID-19 has done to the PSS services that existed before it. The most impacted activities are the supply of food to OVCs, the supply of PPE to caregivers, and funding of PSS programs. Finding project funding and ICT solutions to projects is always difficult and expensive. However, programs that support SDGs and country visions usually get funding priority. For example, the spirit of social integration espoused in His Majesty King Mswati 111's vision 2022 must be used as launch pads for fundraising for projects such as PSS services. Paying lip service and little attention when making COVID-19 policies have long-term implications for the country and the providers of PSS services and the beneficiaries. How a country manages its fundraising programs and relates to its donors determines the amount of donations that flow into the country.

Apart from the foregoing PSS risk-related findings, demographic findings in section $\mathrm{D}$ of the questionnaire raise something interesting regarding whether the participants were going to continue providing the service after COVID 19 or not. The majority (72.4\%) said they will continue. The sensational reason given b $92 \%$ of them is they have passion for children and they feel they have a responsibility to help them. That is why $76.2 \%$ of all the participants have 5 to 15 years of experience in PSS service delivery. Nevertheless, $20 \%$ of those who want to continue wished if management could consider compensating them. However, in light of the finding that leadership and the strategies they developed were becoming risky to the caregivers, some said they were leaving because the system does not recognize them. Furthermore, confirming the impact of COVID 19 on PSS programs, some respondents said they will not come back because they needed to support their spouses who got retrenched under COVID 19 and some claimed the businesses they ran for the families collapsed under COVID 19; hence, they needed to focus on fending for their families.

\section{CONCLUSION AND RECOMMENDATIONS}

The occurrence of COVID-19 puts psychosocial support projects in a terrifying situation that is spurred by an increase in risk exposure, restrictions on freedom of movements, gathering numbers restriction, the physical distress of wearing masks, and forced closures of NCPs. Assessed risks are dangerously high such that the OVCs future is almost doomed, at least for now. The research recommends that, under emergency circumstances, authorities need to take decisions considering the short, medium, and long-term effects of their decisions. For example, terminating certain services such as the closure of NCPs in the name of trying to contain and controlling the spread of COVID-19 has compromised other national or 
international agendas such as Vision 2022's focus on social integration and the first three SDGs of ending poverty, zero hunger and health and wellbeing. Otherwise, management behavior can exacerbate existing challenges. The closing of NCPs ensures OVCs who benefitted from them lose all their benefits. Reintegration of the affected children into society may never happen or will take a very long and expensive route. That is why the New Zealand Ministry of Health (2016) suggested that PSS during an emergency is about easing psychological, social, and physical difficulties for those affected.

The second conclusion from the study is that there is a need for psychosocial safety nets - a climate in which people can raise questions, concerns, and ideas without fear of personal repercussion (Hougaard et al., 2020). Such a transparent process will generate more accurate information and problems will be dealt with from an informed position. Based on the complex nature of managing psychosocial support care among communities, there is a need for accurate assessment of psychosocial support problems under a participatory and multidisciplinary environment. Evidence from the study revealed the existence of ineffective leadership, poor cooperation from communities, poor coordination of $\mathrm{NCP}$ activities, and ineffective strategies which imply poor communication. Consistent communication with communities involved in executing psychosocial support projects is important for communities to remain vigilant to risk reduction, risk readiness, risk response, and risk recovery. Ineffective communication and coordination render these important interventions a nullity.

It can also be concluded from the study that the different risks that affected PSS services, their impacts when they occur, and the impact of COVID 19 on PSS services are dangerously high. However, the study did not identify specific strategies to deal with the identified risks and their potential impacts. It is recommended that authorities reconsider decisions about psychosocial support programs which were made without accurate information and this needs to be done in liaison with the other stakeholders. Government and its partners should be strategizing on how best to channel food, PPE, and other resources to benefit OVCs that relied on NCP services during these difficult times. OVCs are a risk to the nation because of their circumstances. Risks require specific strategies or programs of action. You need strategies to compliment what was on the ground, not to destroy the little you have.

Borrowing from Mahaveer (2020)'s experience in India, we also conclude that Governments implement lockdowns with restrictions to break the chain of COVID 19 transmission, but this can lead to further difficulties for OVCs whose families have got no means to feed and look after them. What this means is that putting hard lockdown conditions for the poor makes their situation worse. As such, the study recommends policy flexibility and discourages unilateralism where every citizen is given the same treatment in terms of restrictions instead of considering specific circumstances for special groups such as the OVCs. Even the WHO (2020) recommendations support the continued availability of community-based services. In addition, authorities must accept accountability for their decisions. For example, in January 2020, the whole Netherlands cabinet had to resign after having caused the collapse of the national children's fund of their country. This demonstrates how serious some people are when making decisions about sensitive issues which involve the management or mismanagement of public funds or programs.

In terms of further research, expanded research that takes into account the views of other stakeholders may result in improved findings and recommendations. We also recommend further research to look into funding options for OVCs so that the problem is not crowded with other PSS issues.

\section{CONFLICT OF INTEREST}

I do hereby confirm that this paper was not funded by anyone except the authors. The authors have no conflicts of interest to declare.

\section{ACKNOWLEDGMENTS}

Acknowledgement is not applicable.

\section{REFERENCES}

Atkinson, S. (2014). The Business Book. $1^{\text {st }}$ Edition. London: Dorling Kindersley.

Bech, C. (2018). Risk Profiles in Project Management. Denmark: Technical University of Denmark (DTU). Retrieved July 11, 2020 from: http://www.apppm.man.dtu.dk/index.php/ Risk_profiles_in_project_management.

Carr, M. J., Konda, S. L., Ulrich, F. C., \& Walker, C. F. (1993). Taxonomy Based RiskIdentification. Pittsburgh, Pennsylvania: Software Engineering Institute, Carnege Mellon University. p15213.

Chandana. (2017). Risk Assessment in Project Management. Retrieved July 11, 2020 from: https://www.simplilearn. com/risk-assessment-project-management-article. 
Collins, C. (2020). Teaching through Corona virus: What Teachers Need Right Now. Teaching Tolerance Magazine. Retrieved from: https://www.learning for justice.org/magazine/teaching-through-coronaviruswhat-educators-need-right-now.Last visited on July 17, 2020. Dhital, R., Shibanuma, A., Miyaguchi, M., Kiriya, J., \& Jimba, M. (2019). Effect of psycho-social support by teachers on improving mental health and hope of adolescents in an earthquake-affected district in Nepal: A cluster randomized controlled trial. PLoS One, 14(10), e0223046.Last visited on August 3,2020.

Dhital, S. Charles Brennan, Michael J. Gidley,(2019). Location and interactions of starches in planta: Effects on food and nutritional functionality, Trends in Food Science \& Technology, Volume 93, Pages 158-166, ISSN 0924-2244, https://doi.org/10.1016/j. tifs.2019.09.011.

Evans, J. R., \& Lindsay, W. M. (2017). Managing for Quality and Performance Excellence. $10^{\text {th }}$ ed. Boston, USA: Cengage Learning.

Fox, W., \& Van Der Walldt, G. (2007). A Guide to Project Management. Cape Town: Juta.

Haugaard, R., Csrter, J. and Mohan, M. (2020). Build Your Resilience in the Face of a Crisis Harvard Business Review, Retrieved on July 10,2020 from:,https://hbr.org/2020/03/ build-your-resilliency-in-the-face-of-a-crisis.

Hlatswhayo, S.(2020).Paramedics not Prepared to go back to Work, Times of Swaziland, 2 August 2020.

International Network for Education in Emergencies [INEE]. (2016). Background Paper on Psychosocial Support and Social and Emotional Learning for Children and Youth in Emergency Settings. Retrieved on 23 June, 2020 from: http://www.toolkit.ineesite. org/resources/ineecms/uploads/1126/20161219_PSS_ SEL_Background_Note_Digital_Final.pdf.

Kaplan, R. S., \& Miles, A. (2012). Managing Risks: A Framework. Brighton, Massachusetts: Harvard Business Review, June Issue.

Kloppenborg, T. J., Anantatmula, V., \& Wells, K. N. (2019). Contemporary Project Management. $4^{\text {th }}$ ed. Boston: Cengage Learning.

Mahaveer, G. (2020). COCID-19, India, lockdown and psychosocial challenges: What next. International Journal of Social Psychiatry, 2020, 1-3.

Mhlanga, T. (2020). COVID-19: Rude awakening to South Africa's Procurement Failures-Corruption Watch September 2020. Retrieved January 8, 2021 from: https:/www.corruptionwatch.org.za/ covid-19-rude-awakening-to-sas-procurement-failures.

Majeed, M. (2018). Risk Management: An Important part of Project Management, PM Project. Retrieved July
12, 2020 from: https://www.project-management. com/risk-management-an-important-part-of-projectmanagement.

Mattingly, J. (2017). Approaches to Providing Psychosocial Support for Children, Teachers and Other School Staff, and Social and Emotional Learning for Children in Protracted Conflict Situations. UK Department for International Development, Education Development Trust Report.

Meredith, J. R., Mantel S. J. Jr., \& Shafer, S. M. (2016). Project Management: A Managerial Approach. $9^{\text {th }}$ ed. Asia: Wiley.

Mutsaka, F (2020). AP News: Zimbabwe's Health Minister Fired over COVID-19 Graft Scandal. Retrieved January 15, 2021 from: https://www.apnews.com/ article/3bc2e7ba1e66b4ae4c8b5a7690713246.

New Zealand Ministry of Health. (2016). Framework for Psychosocial Support in Emergencies, Wellington: Ministry of Health New Zealand. Retrieved on 23 September 2020 from https://www.health.org.nz/publication/ framework-psychosocial-support-emergencies

Oakland, J. S. (2014). Total Quality Management and Operational Excellence. $4^{\text {th }}$ ed. London, New York: Routledge.

Oosthuizen, T., \& Venter, R. (2012). Project Management in Perspective. Cape Town: Oxford University Press.

Project Management Institute. (2008). A Guide to Project Management Body of Knowledge. $4^{\text {th }}$ ed. Pennsylvania, PA: Project Management Institute.

Reeves, M., Lang, N., Carlsson, S., \& Zlezak, P. (2020). Leading Your Business Through the Coronavirus Crisis:12 Lessons from Responding to Covid19. Brighton, Massachusetts: Harvard Business Review.

Schermerhorn, J. R. Jr., \& Bachrach, D. G. (2015). Introduction to Management. $13^{\text {th }}$ ed. Singapore: Wiley.

Sylvia, H. (2020). The Rationale behind Social Distancing and Hand Washing, March 25 2020. Retrieved January 10, 2020 from: https://www.technologynetworks. com/immunology/articles/the-rationale-behind-socialdistancing-and-hand-washing-332559.

The Inter Agency Standing Committee[IASC]. (2007). Guidelines on Mental Health and Psychosocial Support in Emergency Settings. Retrieved on March 23, 2020, from: http://www.interagencystandingcommittee.org/ system/files/legacy_files/Guidelines $\% 20$ IASC $\% 20$ Mental\%20Health\%20Psychosocial\%20\%28with\%20 index $\% 29$.pdf.

The International Federation of Red Cross and Red Cross Crescent (2001).Psychosocial Support Best Practices 
from Red Cross and Red Crescent Programmes (FRC,2001,74 pages).International Federation Reference Centre for Psychosocial Support. Retrieved on 21 August 2020 from helid.digicollection.org/en/d/ Js2902e/4.html

The World Bank. (2020). Eswatini COVID 19 Emergence Response Project (P173883). Project Information Document ID). Retrieved June 1, 2020 from: http://www.documents.worldbank.org/curated/ en/488231586518951359/pdf/Project-InformationDocument-Eswatini-COVID-19-EmergencyResponse-Project-P173883.pdf.

Thuis, P., \& Stuive, R. (2015). Business Administration. Groningen, The Netherlands: Noordhoff Uitgevers, Routledge.

Thuis, P., \& Stuive, R. (2012). Business Administration. Routledge, ISBN: $1000035794,9781000035797$.

United Nations Programme on HIV/AIDS [UNAIDS]. (2006). Report on Global Aids Pandemichttps://data. unaids,org/pub/report2006_gr_en.pdf.Last visited 2 July 2020.
United Nations Children's Fund [UNICEF]. (2008). National Response to Psychosocial Needs of Children: Three Year Strategic Plan 2008-2010. Swaziland Deputy Prime Minister's Office, National Children's Coordination Unit. Retrieved from: http:// www.infocenter.nercha.org.sz/sites/default/files/ infocenter_db/ELDOCS/PSSStra.

United Nations Children's Fund [UNICEF]. (2011). InterAgency Guide to the Evaluation of Psychosocial Programming in Emergencies. New York: United Nations Children's Fund.

World Food Programme. (2018). WFP Eswatini Country Briefing, December 2018. Retrieved on June 30, 2020 from: https://www.reliefweb.int/sites/reliefweb.int/ files/resources/WFP-0000102418.pdf.

World Health Organization[WHO]. (2020). Novel Coronavirus (2019nCov): Strategic preparedness and ResponsePlan.RetrievedJuly2,2020from:https://www. who.int/publications-detail/strategic-preparednessand-response-plan-for-the-new-coronavirus. 